\title{
ANALISIS TINDAK KEJAHATAN GENOSIDA OLEH MYANMAR KEPADA ETNIS ROHINGNYA DITINJAU DARI PERSPEKTIF HUKUM PIDANA INTERNASIONAL
}

\author{
Ketut Alit Putra, Ni Putu Rai Yuliartini, Dewa Gede Sudika Mangku \\ Jurusan IImu Hukum, Fakultas Hukum dan IImu Sosial, Univeritas Pendidikan \\ Ganesha Singaraja, Indonesia \\ e-mail: alitputra1993@yahoo.com, raiyuliartini@gmail.com, \\ dewamangku.undiksha@gmail.com,
}

\begin{abstract}
Abstrak
Masyarakat rohingya telah mengalami berbagai bentuk pelanggaran hak asasi manusia yang termasuk pada kejahatan genosida terutama sejak tahun 1978. Hak kebebasan untuk bergerak bagi orang-orang rohingya dibatasi secara ketat dan dikeluarkannya Undang-Undang Citizhenship Law yang mengakibatkan Myanmar dengan bebas melakukan diskriminasi kepada masyarakat yang tidak memiliki status kewarganegaraan. Permasalahan yang diangkat pada penelitian ini yaitu tindakan yang dilakukan oleh Myanmar merupakan sebuah kejahatan genosida, serta upaya penyelesaian sengketa antara Myanmar dengan etnis rohingnya. Jenis penelitian ini menggunakan jenis penelitian hukum normatif yaitu dengan studi kepustakaan dan literatur- literatur yang berkaitan dengan genosida, serta menggunakan pendekatan sejarah, pendekatan perundang-undangan, pendekatan konsep dan pendekatan kasus. Hasil dari penelitian ini menyatakan bahwa tindakan yang dilakukan oleh Myanmar kepada etnis muslim rohingnya memang benar merupakan suatu kejahatan genosida, yang didasari dari beberapa unsur sesuai dengan Pasal 6 Statuta Roma 1998. Upaya Penyelesaian Sengketa dilakukan secara litigasi, karena penyelesaian secara non litigasi tidak dapat menemukan titik terang dari sengketa tersebut, dan yang menangani kasus tersebut adalah Mahkamah Pidana Internasional dengan pengadilan ICC. Kesimpulannya bahwa Myanmar telah melakukan tindak kejahatan genosida terhadap etnis rohingnya serta diskriminasi terhadap kaum minoritas. Selanjutnya upaya dari penyelesaian sengketa tersebut dilakukan dengan cara litigasi atau melalui mekanisme hukum dan ditangani oleh ICC (International Criminal Court).
\end{abstract}

Kata Kunci: Rohingnya, Genosida, International Criminal Court

\begin{abstract}
Rohingya community has experienced various forms of human rights violations that include genocide crimes, especially since 1978. The right to freedom of movement for the spirits is tightly restricted and the issuance of the Citizenship Law Act which resulted in Myanmar freely discriminating against people who are not has a citizenship status. The issues raised in this study are the actions undertaken by Myanmar is a crime of genocide, as well as efforts to resolve disputes between Myanmar and ethnic spirits. This type of research uses the type of normative legal research that is by literature studies and literature related to genocide, and using historical approaches, statutory approaches, concept approaches and case approaches. The results of this study indicate that the actions taken by Myanmar to the spirits of the Muslim community are indeed a genocide crime, based on some elements in accordance with Article 6 of the Rome Statute 1998. The Dispute Resolution is litigated, as nonlitigation settlements can not find the bright spot of the dispute, and who handles the case is the International Criminal Court with the ICC tribunal. The conclusion is that Myanmar has committed genocide crimes against its ethnic spirits and discrimination against minorities. Furthermore, the efforts of dispute settlement are conducted by litigation or through legal mechanism and handled by ICC (International Criminal Court).
\end{abstract}

Keywords: Rohingnya, Genocide, International Criminal Court 


\section{PENDAHULUAN}

Istilah hukum pidana internasional semula diperkenalkan dan dikembangkan oleh pakar-pakar hukum internasional dari Eropa daratan seperti Freiderich Meili pada tahun 1910 dari Swiss, Georg Schwarzenberger pada tahun 1950 dari Jerman, Gerhard Mueller pada tahun 1965 dari Jerman, J.P Francois pada ta hun 1967, Rolling dan Van Bemmelen pada tahun 1979 dari Belanda, kemudian diikuti oleh pakar hukum dari Amerika Serikat seperti Edmund Wise pada tahun 1965 dan Cherif Bassiouni pada tahun 1986 (Efendi, $2014: 37$ ).

Pidana Internasional menunjukkan adanya suatu peristiwa kejahatan yang sifatnya internasional, yaitu kejahatankejahatan yang diatur dalam konvensikonvensi internasional sebagai tindak pidana internasional. Adapun yang dimaksud dengan hukum pidana internasional adalah hukum yang menentukan hukum pidana nasional yang akan diterapkan terhadap kejahatankejahatan yang nyata-nyata telah dilakukan bilamana terdapat unsur-unsur internasional didalamnya antara lain individu, negara, dan badan swasta. Hukum pidana internasional sebagai cabang ilmu baru dalam sejarah perkembangannya tidak terlepas dan bahkan berkaitan erat dengan sejarah perkembangan Hak Asasi Manusia (Effendi, 2014 : 34).

ICC adalah pengadilan permanen dan independen yang mampu melakukan penyelidikan dan mengadili setiap orang yang melakukan pelanggaran berat terhadap kejahatan internasional. Hukum pidana internasional memiliki sumber utama yaitu Statuta Roma. Statuta Roma 1998 tentang pendirian International Criminal Court, Mahkamah Pidana Inernasional yang bersifat permanen merupakan dasar hukum bagi pembentukan dan keberlakuan dari Pengadilan Pidana Internasional atau International Criminal Court (ICC). Sejak disahkan tanggal 17 Juli 1998, Statuta Roma telah mengalami perubahan melalui review conference yang diadakan di Kampala dari tanggal 21 Mei-11 Juni 2010. Genosida yang diartikan sebagai pembunuhan dengan sengaja, penghancuran atau pemusnahan kelompok atau anggota kelompok tersebut, pertama kali dipertimbangkan sebagai subkatagori dari kejahatan terhadap kemanusiaan (Effendi, 2014 : 111).

Pengaturan terkait dengan genosida antara lain, piagam mahkamah militer internasional Nurnberg, Konvensi Genosida 1948, Statuta ICTY, Statuta ICTR, Statuta Roma 1998. Sedangkan lembaga pemidanaan genosida antara lain, Pemidanaan oleh Pengadilan Nasional, Pemidanaan oleh Pengadilan Hibrida, dan Pemidanaan oleh Mahkamah Pidana Internasional. Mahkamah Militer Internasional Nurnberg dan Mahkamah Militer Internasional Tokyo merupakan titik dasar bagi pembentukan mahkamah kejahatan internasional pada masa berikutnya yaitu, Mahkamah Militer Internasional Nurnberg, International Criminal Tribunal for the Former Yugoslovia (ICTY), International Criminal Tribunal for Rwanda (ICTR), International Criminal Court (ICC) (Siswanto, 2015 : 83). Data dari Amnesty International 2011-2017, setelah konflik ini mulai berkecamuk, orang-orang Rohingnya telah mengalami penderitaan yang cukup panjang akibat pelanggaran Hak Asasi Manusia yang dilakukan oleh Pemerintah Junta Myanmar. Kebebasan bergerak orang Rohingnya sangat terbatas, mereka juga mengalami berbagai bentuk pemerasan dan dikenakan pajak secara sewenang-wenang, perampasan tanah, pengusiran paksa, dan penghancuran rumah dan pengenaan biaya administrasi yang tinggi pada pernikahan. Sebenarnya perselisihan antara etnis Rohingnya dan pemerintah Myanmar bukanlah konflik tentang agama, yakni berdasarkan Pasal 3 Burma Citizenship Law tahun 1982 menyatakan bahwa rohingnya hanya merupakan warga pendatang yang ditempatkan oleh kolonial Inggris dari Bhanglades hal tersebut ditegaskan kembali oleh pernyataan Menteri Luar Negeri Myanmar pada 21 Februari 1992. Etnis muslim rohingnya merupakan imigran gelap dan belum mendapat status kewarganegaraan dari pemerintah 
Myanmar. Oleh karena hal tersebut sehingga pemerintah Myanmar melakukan diskriminasi terhadap etnis muslim rohingnya tersebut.

Mereka telah dipekerjakan sebagai buruh paksa di jalan dan di kamp-kamp militer, meskipun jumlah tenaga kerja paksa di Rakhaing utara telah menurun selama beberapa tahun terkhir. Perlakuan diskriminatif tersebut telah memaksa mereka memilih untuk menjadi manusia perahu dan meninggalkan Myanmar untuk mencari keamanan di negara lain. Negaranegara yang menjadi tempat transit dan tujuan mereka antara lain adalah Bangladesh, Malaisya, Pakistan, Saudi Arabia, Thailand, Indonesia, dan Australia (Faniati, 2102 : 8). Sebenarnya perselisihan antara etnis Rohingnya dan pemerintah Myanmar bukanlah konflik tentang agama, yakni berdasarkan Pasal 3 Burma Citizenship Law tahun 1982 menyatakan bahwa rohingnya hanya merupakan warga pendatang yang ditempatkan oleh kolonial Inggris dari Bhanglades hal tersebut ditegaskan kembali oleh pernyataan Menteri Luar Negeri Myanmar pada 21 Februari 1992.

Etnis muslim rohingnya merupakan imigran gelap dan belum mendapat status kewarganegaraan dari pemerintah Myanmar. Oleh karena hal tersebut sehingga pemerintah Myanmar melakukan diskriminasi terhadap etnis muslim rohingnya tersebut. Masyarakat rohingya telah mengalami berbagai bentuk pelanggaran hak asasi manusia yang termasuk pada tindakan genosida terutama sejak tahun 1978. Hak kebebasan untuk bergerak bagi orang-orang rohingya dibatasi secara ketat dan sebagian besar dari mereka tidak diakui sebagai warga negara Myanmar. Tujuan dari penelitian ini terdiri dari tujuan yang pertama tujuan umum dan kedua tujuan khusus yaitu, tujuan umum dari penelitian ini bertujuan untuk mengetahui sejarah mengenai etnis Rohingya di Myanmar. Untuk menambah ilmu pengetahuan terutama dibidang hukum pidana Internasional mengenai Genosida, dan Peradilan Pidana Internasional. Tujuan khusus dari penelitian ini yaitu yang pertama bertujuan untuk menganalisa dan mengetahui tindakan yang dilakukan oleh
Myanmar kepada etnis rohingnya merupakan tindak kejahatan genosida. Tujuan yang selanjutnya yaitu bertujuan untuk mengetahui upaya penyelesaian sengketa antara Pemerintah Myanmar dengan etnis rohingnya ditinjau dari perspektif hukum pidana internasional. Dari latar belakang diatas, peneliti mendapat dua rumusan maslah yaitu, apakah tindakan kejahatan yang dilakukan oleh Myanmar merupakan tindak kejahatan genosida, serta bagamana upaya penyelesaian sengketa yang terjadi antara Myanmar dengan etnis rohingnya ditinjau dari perspektif hukum pidana internasional.

\section{METODE PENELITIAN}

Peneletian adalah suatu sarana pokok dalam pengembangan ilmu pengetahuan maupun teknologi. Karena penelitian merupakan suatu sarana bagi pengembangan ilmu pengetahuan dan teknologi, maka metodologi penelitian yang diterapkan harus senantiasa disesuaikan dengan ilmu pengetahuan yang menjadi induknya. Hal ini tidaklah selalu berarti metodologi penelitian yang dipergunakan berbagai ilmu pengetahuan pasti akan berbeda secara utuh. Akan tetapi setiap ilmu pengetahuan mempunyai identitas masingmasing, sehingga pasti aka nada berbagai perbedaan (Soekanto dan Mamuji, $2015: 1$ ). Jenis penelitian yang digunakan peneliti dalam penelitian ini merupakan jenis penelitian hukum normatif, penelitian hukum normatif yaitu penelitian yang dilakukan dengan cara mengkaji peraturan perundangundangan yang berlaku atau diterapkan terhadap suatu permasalahan hukum tertentu. Penelitian normatif seringkali disebut dengan penelitian doktrinal, yaitu penelitian yang objek kajiannya adalah dokumen peraturan perundang-undangan dan bahan pustaka (Soejono dan Abdurahman, 2003:56). Dikatakan bahwa pendekatan perundang- undangan berupa legislasi dan regulasi yang dibentuk oleh lembaga negara atau pejabat yang berwenang dan mengikat secara umum (Geraldi, 2013: 18).

Sumber Hukum Primer: yaitu bahan hukum yang bersifat autoritatif artinya mempunyai otoritas. Dalam hal ini aturanaturan seperti Statuta Roma 1998, Statuta 
ICTY, Statuta ICTR, Statuta Tokyo dan Statuta Nurnberg. Sumber Hukum Sekunder: yaitu semua publikasi tentang hukum yang bukan merupakan dokumendokumen resmi, Sumber bahan hukum tersier yaitu bahan yang memberikan petunjuk atau penjelasan tambahan terhadap bahan hukum primer dan sekunder yang terdapat dalam penelitian.

Teknik pengumpulan bahan hukum yang dilakukan adalah dengan cara menggali kerangka normatif menggunakan bahan hukum yang membahas tentang teori-teori hukum, perlindungan hak asasi manusia terhadap kaum muslim Rohingya. Baik bahan hukum primer maupun bahan hukum sekunder dikumpulkan berdasarkan topik permasalahan yang telah dirumuskan berdasarkan sistem kartu dan diklasifikasi menurut sumber dan hierarkinya untuk dikaji secara kompeherensif.

\section{HASIL DAN PEMBAHASAN \\ Tindakan yang dilakukan oleh Myanmar terhadap etnis rohingnya merupakan kejahatan Genosida}

Genosida menurut pasal 6 Statuta Roma 1998 merupakan kejahatan yang dilakukan secara sistematis dengan tujuan untuk menghancurkan seluruh atau sebagian etnis, ras, suku, dan agama seperti :

(a). Membunuh suatu kelompok;

(b). Menyebabkan luka parah atau merusak mental suatu kelompok;

(c). Dengansengaja mengancam jiwa suatu kelompok yang menyebabkan luka fisik baik sebagian maupun keseluruhan;

(d). Melakukan tindakan yang dimaksudkan untuk mencegah kelahiran dalam kelompok;

(e). Memindahkan anak-anak secara paksa dari satu kelompok-ke kelompok lain.

Secara etimologis, istilah genosida berasal dari bahasa Yunani, „Geno', yang berarti "ras" dan kata Latin "cidium" yang berarti "membunuh". Dengan demikian secara harfiah, genosida diartikan sebagai pembunuhan terhadap rasa atau pemusnahan ras. Genosida yang diartikan sebagai pembunuhan dengan sengaja, penghancuran atau pemusnahan rasa atau anggota kelompok tersebut, pertama kali dipertimbangkan sebagai subkatagori dari kejahatan terhadap kemanusiaan (Effendi, 2014 : 111).

Istilah ini tercatat pertama kali dipopulerkan oleh Raphael Lemkin pada tahun 1944 untuk menunjuk pada peristiwa pembantaian secara sistematis dan luas terhadap kaum Yahudi di Eropa. Oleh karena itu, sangat tepat sekali apa yang dikemukakan oleh sosiolog Leo Kuper bahwa meskipun genosida adalah sebuah istilah yang baru, namun apa yang terkandung didalam istilah tersebut sesungguhnya merupakan sebuah konsep yang lama (Siswanto, $2015: 27$ ).

Faktor-faktor penyebab terjadinya Genosida antara lain disebabkan oleh :

a) Faktor Ras

Faktor yang petama tentang perbedaan ras oleh beberapa kelompok di dunia mengakibatkan penyebab terjadinya kejahatan genosida seperti yang pernah terjadi di Afrika Selatan pada abad ke-17, yaitu bermula dari kasus mengenai Apartheid. Peristiwa ini muncul karena setelah kemerdekaan bangsa Afrika Selatan dari penjajahan oleh Inggris dan Belanda, pada saat itu telah terbentuk dua kelompok yang akan menguasai Afrika Selatan. Diantara kelompok-kelompok yang ingin menguasai Negara Afrika Selatan maka salah satu Partai Nasionalis yang telah memenangkan dan menguasainya. Taktik dan strategi Partai Nasionalis dalam menjalankan

kekuasaannya salah satunya menciptakan konflik Apartheid sebagai suatu cara untuk mempererat control mereka atas bentuk sistem ekonomi dan sosial (Widyawati, 2014 :64).

b) Faktor Suku

Penyebab yang dapat menimbulkan terjadinya kejahatan genosida selanjutnya ialah karena latar belakang suku dari suatu kelompok. Permasalahan yang timbul karena diskriminasi suku (etnis), pelanggaran-pelanggaran hak yang dilakukan kepada kelompok minoritas. Menurut Colier, menyatakan bahwasannya konflik etnis bukan hanya disebabkan karena perbedaan etnis secara umum, agama, politik, dan perkembangan ekonomi, tetapi melainkan juga karena dapat disebabkan oleh masyarakat sipil di 
suatu tempat itu sendiri (Widyawati, 2014 : 65).

c) Faktor Agama

Faktor yang dapat menyebabkan kejahatan genosida selanjutnya adalah agama, seperti dengan faktor-faktor pemicu sebelumnya bahwa latar belakang agama sangat mendasar timbulnya perpecahan antar satu kelompok dengan kelompok lainnya. Dimana agama yang minoritas akan selalu ditindas oleh agama yang tergolong mayoritas di suatu tempat yang terdapat kekerasan terhadap kemanusiaan. Konflik yang ditimbulkan karena faktor agama memang lebih ekstrim untuk terjadinya kekerasan bahkan penyerangan terhadap masyarakat yang beragama lain (Widyawati, 2014 : 66). Perpecahan yang timbul karena faktor agama akan terus berkelanjutan terjadi apabila dalam suatu kelompok tidak mempunyai inisiatif melakukan penyelesaian masalah yang menjadi penyebab dari konflik itu sendiri. Peran utama terletak pada para pemuka agama, sesepuh dan tokoh pada suatu agama yang mempunyai otoritas dan kepercayaan dalam membina dan mengarahkan kelompoknya untuk tidak melakukan kekerasan terhadap sesame manusia (Widyawati, 2014 : 66).

Myanmar merupakan salah satu Negara di Asia Tenggara, jadi penulisan sejarah lengkap tentang Burma (sekarang Myanmar), khususnya di wilayah Arakan belum mampu diperjelas oleh para sejarawan secara objektif. Sejauh ini telah terbit berbagai tulisan sejarawan modern tentang peristiwa yang relevan dengan sejarah di Arakan. Sumber lama tentang sejarah Arakan juga telah tersedia, baik berupa kronik, buku sejarah, maupun artikel yang ditulis dalam bahasa Burma oleh beberapa peneliti, namun masih memunculkan kontroversi dan distorsi karena adanya bias kepentingan kelompok yang kuat (Bustamam, 2013 : 311) Beberapa bulan terakhir, Burma telah menjadi berita utama terkait pelanggaran Hak Asasi Manusia, khususnya kasus diskriminasi terhadap etnis minoritas muslim. Istilah Rohingnya kemudian menjadi sangat kontroversial. Etnis Rohingnya juga sering dikaitkan dengan etnis, bahasa, dan agama dari Bengali yang menetapdi wilayah Chitaggong. Banyak anggapan mengatakan bahwa Muslim Bengali di Arakan saat ini datang bersamaan dengan kolonial Inggris abad ke-19 dan ke20. Rohingnya sering dikaitkan dengan imigran gelap akibat perang kemerdekaan dan bencana topan pada tahun 1978 dan 1991. Ada juga penilaian bahwa mereka ingin mengukuhkan statuts kewarganegaraan sebagaimana etnis pribumi lainnya, diantaranya seperti Shan, Karen, Kachin, dan Chin (Bustamam, 2013 : 312)

Secara umum, baik versi pemerintahan, sejarawan, maupun akademisi lebih cendrung mempublikasikan bahwa di Burma terdapat 135 suku, yang terbesar antara lain suku Burman, Chin, Kachin, Shan, Arakan, Kayah, Karen, dan Mon. Meskipun pemerintah mengklaim terdapat

135 etnis, tidak ditemukan data resmi terkait jumlah etnis minoritas di Burma. Kachin, Karen, Kareni, Shan, Chin, Mon dan Arakan merupakan etnis yang dapat dilacak garis keturunannya dan menegosiasikan batasbatas wilayahnya dengan pemerintah.

Populasi etnis di Burma terdiri dari etnis Burman yang merupakan mayoritas sebanyak 50 juta orang (50-75\%). Kelompok minoritas terbesar berikutnya adalah Shan (9\%) dan Karen (7\%). Sedangkan etnis Mon, Arakan, Chin, Kachin, Karen, Rohingnya, Kayan, Cina, India, Danu, Akha, Kokang, Lahu, Naga, Palaung, Pao, Tavoyan, dan Wa populasinya hanya sekitar $5 \%$ atau dibawah angka itu (Bustamam, 2013 : 317).

Rohingnya merupakan oaring-orang muslim yang tinggal di kawasan Arakan di barat Myanmar. Menurut Persatuan BangsaBangsa, rohingnya merupakan salah satu minoritas yang paling dianiaya di dunia. Banyak masyarakat Rohingnya telah melarikan diri ke tempat aman dan kam-kam pelarian di Bangladesh jiran, dan kawasan di sepanjang sepadan Thai- Myanmar. Sudah kita ketahui bersama bahwasannya kejahatan genosida merupakan kejahatan yang paling serius yang dibicarakan oleh dunia pada saat ini, dikarenakan genosida merupakan suatu kejahatan yang berniat untuk 
memusnahkan etnis, ras dan agama pada kelompok tertentu.

Kejahatan genosida yang dilakukan oleh pemerintah Myanmar terhadap etnis rohingnya adalah suatu tindakan yang sudah melanggar Hak Asasi Manusia masyarakat rohingnya. Pelanggaran HAM yang cukup berat terjadi, terdapat dua reaksi umum yang timbul dari masyarakat rohingnya, yakni tetap tinggal di Myanmar atau memilih menjadi pengungsi di negara lain (Soetjipto, 2015 : 132). Masyarakat rohingnya yang bertahan mengalami perlakuan yang tidak manusiawi dan semakin tertindas dengan tidak diakuinya mereka sebagai warga negara Myanmar, tidak diakuinya rohingnya sebagai warga negara Myanmar menyebabkan masyarakat rohingnya menjadi stateless person. Konflik besar yang mempengaruhi pihak-pihak yang terlibat, dalam hal ini pemerintah Myanmar dengan etnis muslim rohingnya (Soetjipto, $2015: 132$ ).

Genosida di Myanmar ditandai dengan pembunuhan muslim rohingnya oleh penduduk Myanmar penganut Buddha pada tahun 1938, penangkapan besar-besaran tahun 1970, dan pemberlakuan undangundang kewarganegaraan tahun 1982 yang secara structural membuat eksistensi masyarakat rohingnya illegal di mata hukum (Soetjipto, 2015 : 133).

Tindakan diskriminasi yang diterima oleh masyarakat rohingnya telah terjadi semenjak tahun 1938 dan sebanyak 30.000 muslim rohingnya telah dibunuh pada $26 \mathrm{Juli}$ 1938. Kejadian yang sama telah terjadi berulang pada tahun 1942, 1968, 1992, dan memuncak pada tahun 2012 (Froyoplus, 2012). Pada tahun 1982 pemerintah Myanmar dengan resmi menerbitkan undang-undang "Burma Citizenship Law 1982" yang bersifat diskriminasi kepada etnis rohingnya (Karuniawan, 2012 : 11). Sejak diterbitkannya undang-undang tersebut anak-anak etnis rohingnya tidak mendapatkan hak pelajaran mereka dan mengakibatkan anak-anak tersebut tidak menyambung pelajarannya serta mendapat berbagai tekanan seperti ekonomi, penangkapan, penyiksaan, dan jenis diskriminasi lainnya (Karuniawan, 2012 : 11).
Keadaan semakin memburuk dan menyedihkan ketika wanita muslim rohingnya dilarang untuk mengenakan hijab, banyak diantara mereka yang ditindas, mengalami diskriminasi, dan kekerasankekerasan lainnya. Masyarakat rohingnya juga mendapat diskriminasi pada bidang kesehatan, masyarakat rohingnya tidak mendapat perlakuan sama di rumah sakit maupun klinik-klinik di Myanmar. Masyarakat rohingnya dipaksa untuk membayar harga pengobatan dan biaya rumah sakit sangat mahal dibandingkan dengan masyarakat Myanmar (Karuniawan, $2012: 11)$.

Tindakan genosida yang dialami etnis rohingnya terjadi dalam berbagai bentuk seperti pemerkosan, pembunuhan penindasan terhadap anak-anak, perampasan rumah, tanah, pemusnahan dan dilarang untuk memperbaiki masjid, penggantian masjid dengan pagoda Buddha, pergerakan dan perkawinan mereka dibatasi, penangkapan dan penyiksaan tanpa bicara, serta pemaksaan keluar dari islam dan menganut Buddha (Karuniawan, 2012 : 12).

Tindakan genosida yang dilakukan Myanmar terhadap etnis rohingnya merupakan tindakan yang sangat kejam karena sudah menghilangkan Hak Asasi Manusia masyarakat etnis rohingnya. Tindakan yang dilakukan seperti membunuh, memperkosa, memusnahkan, membakar, tidak memberikan untuk menganut agamanya masing-masing, berencana untuk memusnahkan etnis rohingnya merupakan kejahatan genosida yang sangat serius. Di harapkan Perserikatan Bangsa-Bangsa harus bertindak dalam hal ini agar kasus ini secepatnya selesai serta tidak ditemukannya lagi kasus serupa yang terjadi di Negara lain.

Dari pemaparan di atas, peneliti dapat menarik hasil terkait dengan tindakan yang dilakukan oleh Pemerintah Myanmar terhadap etnis rohingnya sudah memenuhi unsur bahwa tindakan tersebut dapat dikatagorikan sebagai tindakan kejahatan genosida. Syarat dari sebuah tindakan tersebut dapat dikatakan sebagai tindakan genosida, apabila sudah memenuhi unsurunsur seperti pembunuhan masal, 
dilakukan secara sistematis, diskriminasi terhadap suatu agama, dan bertujuan melenyapkan suatu etnis atau golongan tertentu yang jumlahnya minoritas. Maka dari hal tersebut dapat peneliti uraikan bahwasannya tindakan yang dilakukan oleh pemerintah Myanmar tersebut sudah memenuhi unsur-unsur diatas, bahkan melebihi dari unsur pokok yang ada, sehingga dapat disimpulkan bahwa tindakan yang dilakukan oleh pemerintah Myanmar terhadap etnis muslim rohingnya merupakan tindak kejahatan internasional genosida.

\section{Upaya Penyelesaian Sengketa Antara Pemerintah Myanmar Dengan Etnis Rohingnya Ditinjau Dari Perspektif Hukum Pidana Internasional}

Penyelesaian sengketa internasional merupakan cara yang digunakan untuk menyelesaikan masalah yang dihadapi negara-negara yang sedang bersengketa. Secara umum penyelesaian sengketa yang sudah kita ketahui bersama antara lain penyelesaian sengketa melalui pengadilan dan di luar pengadilan atau litigasi dan non litigasi.

$\begin{array}{cc}\text { Upaya } & \text { Penyelesaian sengketa } \\ \text { internasional merupakan cara yang }\end{array}$ digunakan untuk menyelesaikan masalah yang dihadapi negara-negara yang sedang bersengketa. Secara umum penyelesaian sengketa yang sudah kita ketahui bersama antara lain penyelesaian sengketa melalui pengadilan dan di luar pengadilan atau litigasi dan non litigasi. Penyelesaian Sengketa di luar pengadilan merupakan penyelesaian sengketa yang dilakukan tidak didepan hakim melainkan di depan mediator atau orang ketiga yang sudah ditunjuk sebelumnya, penyelesaian sengketa di luar pengadilan meliputi :

a. Negosiasi, merupakan cara penyelesaian sengketa yang paling dasar yang digunakan oleh masyarakat, banyak sengketa yang diselesaikan setiap harinya dengan cara ini alasan utamanya yaitu bahwa dengan cara ini, para pihak dapat mengawasi prosedur penyelesaian sengketanya dan setiap penyelesaiannya didasarkan pada kesepakatan-kesepakatan dari kedua belah pihak (Winarwati, 2017 : 78). b. Mediasi, adalah cara penyelesaian sengketa melalui pihak ketiga atau seorang mediator. Mediator tersebut bisa berasal dari Negara, organisasi internasional seperti PBB, politikus, ahli hukum, dan seorang ilmuan. Mediator tersebut ikut serta secara aktif dalam proses mediasi tersebut, biasanya seorang mediator dengan kapasitasnya sebagai pihak yang netral berupaya mendamaikan para pihak dengan memberikan saran untuk menyelesaikan sengketa tersebut (Winarwati, 2017 : 79).

c. Konsiliasi adalah cara penyelesaian sengketa yang sifatnya lebih formal disbanding mediasi. konsiliasi merupakan suatu cara penyelesaian sengketa oleh pihak ketiga atau oleh suatu komisi yang dibentuk oleh para pihak, komisi ini disebut komisi konsiliasi. komisi ini berfungsi untuk menetapkanpersyaratan penyelesaian sengketa yang diterima oleh para pihak, tetapi putusannya tidak mengikat kedua belah pihak (Winarwati, 2017 : 80).

Pada tahun 1994, Majelis Umum PBB memutuskan untuk berusaha mewujudkan berdirinya Mahkamah Pidana Internasional, dengan membawa rancangan statuta dari Komisi Hukum Internasional sebagai sebuah dasar rancangan tersebut dibahas di Komisi Ad Hoc yang bertemu sebanyak dua kali sepanjang tahun 1995 (Effendi, 2014 : 240). Setelah rancangan tersebut selesai dibahas oleh Komisi Ad Hoc, Majelis Umum PBB berdasarkan Resolusi Majelis Umum nomor 5216 (LII) yang diadopsi tahun 1996 dan 1997 membentuk Komisi Persiapan untuk menindaklanjuti hasil dari Komisi Ad Hoc. Pada tanggal 15 sampai dengan 17 Juli 1998 diadakan suatu konfrensi diplomatik yang diadakan di Roma dan dihadiri oleh wakil dari Negara- negara di dunia, organisasi-organisasi pemerintah, dan organisasi-organisasi non- pemerintah.

Setelah naskah berhasil dipersiapkan dari tahun 1994 oleh Komisi Hukum Internasional, kemudian diserahkan kepada Majelis Umum PBB dan ditahun yang sama Majelis Umum membentuk Komisi ad hoc untuk meninjau aspek-aspek substantif, administratif, dan prosedural (Parthiana, 
2015 : 357). Pada tahun 1994 naskah diserahkan untuk ditindaklanjuti dan dibahas oleh Majelis Umum yang sudah membentuk Komisi Persiapan untuk membahasnya secara lebih mendalam dari tahun 1995-1997 dan pada bulan April tahun 1998 Komisi Persiapanberhasil merampungkan tugasnya yang kemudian menghasilkan naskah final dan autentik tentang Statuta Mahkamah Pidana Internasional. Naskah final ini kemudian dibawa dan dibahas pada Konfrensi pada tanggal 15-17 Juli 1998 di Roma kemudian naskah tersebut ditandatangani oleh para wakil Negara-negara, dan semua wakil undangan yang hadir pada saat Konfrensi Diplomatik tersebut (Parthiana, 2015 : 357). Semenjak naskah yang sudah diautentikasi serta ditandatangani oleh semua perwakilan yang hadir pada Konfrensi tersebut, maka pada saat itu pula tanggal 17 Juli 1998 Mahkamah Pidana Internasional telah sah dibentuk sebagai suatu badan pengadilan pidana internasional yang bersifat permanen namun baru sah berdiri pada tahun 2002 setelah syarat 60 negara meratifikasi

Statuta Roma 1998 tersebut terpenuhi. Berkedudukan di Den Haag Belanda,

Statuta secara keseluruhan terdiri dari 13 bagian dan terdiri dari 128 Pasal (Parthiana, 2015 : 358).

Kejahatan-kejahatan yang terjadi dalam lingkup internasional harus diselesaikan melalui badan peradilan apabila secara perdamaian tidak bisa menyelesaikannya. Kejahatan-kejahatan seperti genosida, kejahatan perang, kejahatan terhadap kemanusiaan, dan kejahatan agresi yang menyangkut maslah internasional secara keseluruhan, dapat dihukum. Dengan demikian pendirian Mahkamah Pidana Internasional yang permanen dinilai penting bagi penuntutan kejahatan internasional di masa yang akan datang (Iswadi, $2014: 2$ ). Pengaturan Mahkamah Pidana Internasional di dalam Statuta Roma yaitu tertuang pada Pasal 125 ayat 2 dan 3, Pasal 126 ayat 1 , Pasal 4 ayat 1 , Pasal 4 ayat 2, Pasal 3 ayat 2 (Siswanto, 2015 : 358). Statuta Roma 1998 merupakan dasar bagi terbentuknya Mahkamah Pidana Internasional yang bertujuan untuk dapat memberikan sebuah kepastian bagi para korban tindak pidana internasional berat, bahwa para pelaku tindak pidana tidak bisa lepas dari pertanggungjawaban pidana atas perbuatannya (Effendi, 2014 : 239).

Upaya penyelesaian sengketa merupakan cara untuk suatu pengadilan dalam rangka menyelesaiakan suatu sengketa yang terjadi di suatu Negara. Dalam hal ini yaitu upaya penyelesaian sengketa yang terjadi di Negara Myanmar antara pemerintah Myanmar dengan etnis muslim rohingnya. Dalam rangka menyelesaiakan sengketa yang terjadi antara pemerintah Myanmar dan etnis muslim rohingnya, sesuai dengan Pasal 33 Piagam PBB terlebih dahulu sebaiknya menggunakan cara diplomasi, apabila tidak menemukan titik terang dalam permasalahan ini maka baru beralih dengan menggunakan cara hukum yakni melalui peradilan (Susanti, 2014 : 16).

Dalam Pasal 31 Piagam Perserikatan Bangsa-Bangsa dijelaskan dalam dua ayat yakni;

ayat (1) : Pihak-pihak yang termasuk dalam pertikaian yang jika berlangsung secara terus menerus mungkin akan membahayakan perdamaian dan keamanan nasional, pertama-tama harus mencari penyelesaian sengketa dengan jalan perundingan, penyelidikan, mediasi, konsiliasi, arbitrasi, penyelesaian sengketa menurut hukum melalui badan-badan atau peraturan-peraturan regional, atau dengan cara damai lainnya yang dipilih kedua belah pihak.

ayat (2) : Bila dianggap perlu, Dewan Keamanan PBB meminta kepada pihakpihak bersangkutan untuk menyelesaikan pertikaiannya dengan cara-cara yang serupa itu.

Kejahatan yang dilakukan oleh pemerintah Myanmar terhadap etnis muslim rohingnya merupakan kasus kejahatan genosida, karena sesuai dengan pengertian genosida Pasal 6 Statuta Roma genosida merupakan kejahatan yang bertujuan untuk menghapuskan etnis, ras, dan agama baik secara menyeluruh atau sebagian. Untuk menyikapi kasus tersebut yang terjadi di Myanmar terhadap etnis muslim rohingnya, PBB memang telah mengecam keras kepada pemerintah Myanmar untuk segera mengakhiri kekerasan yang terjadi dan 
sudah berlangsung sangat lama. Namun, hal tersebut tidak ditanggapi dengan baik oleh pemerintah Myanmar dan hingga saat ini masih belum ada upaya dalam penyelesaian sengketa tersebut.

Dalam sengketa ini cara diluar jalur hukum, seperti mediasi, konsiliasi, dan negosiasi sudah pernah dipakai untuk upaya penyelesaian sengketa namun belum juga menemukan titik terang dalam sengketa tersebut. Jika dalam menggunakan cara diluar pengadilan sudah pernah digunakan oleh Negara dalam mengakhiri sengketa yang terjadi, namun masih belum menemukan titik temu, maka dalam kasus ini dapat diambil alih oleh Dewan Keamanan PBB untuk diselesaikan menggunakan cara melalui Mahkamah Pidana Internasional (Susanti, 2014 : 17). Didalam yurisdiksi Mahkamah Pidana Internasional terdapat empat yurisdiksi, yaitu :

a. Yurisdiksi Material : Mahkamah pidana internasional berwenang untuk mengadili kejahatan-kejahatan yang diatur didalam Statuta Roma 1998 yaitu dalam Pasal 6 samapai dengan Pasal 8 antara lain, genosida, kejahatan kemanusiaan, agresi, dan kejahatan perang (Parthiana, 2015 : 361). Berkaitan dengan kasus yang terjadi di Myanmar kejahatan yang terjadi yaitu kejahatan genosida.

b. Yurisdiksi Personal : Dalam Pasal 25 Mahkamah Pidana Internasional hanya mengadili individu tanpa memandang status sosial dari individu tersebut, apakah seorang pejabat Negara atau sebagainya (Susanti, 2014 : 18). Berkaitan dengan kasus di Myanmar yang bertanggung jawab adalah individu.

c. Yurisdiksi Teritorial : Mahkamah Pidana Internasional dapat mengadili kasuskasus yang terjadi di Negara peserta dimana menjadi atau terjadinya kejahatan. Hal ini diatur dalam pasal 12 Statuta Roma 1998 (Effendi, 2014 : 245).

d. Yurisdiksi Temporal : Sesuai dengan Pasal 11 ayat (1) dan (2) Statuta Roma 1998, bahwa Mahkamah Pidana Internasional hanya berwenang untuk mengadili kejahatan-kejahatan yang terjadi setelah berlakunya Mahkamah Pidana Internasional yakni pada 1 Juli 2002 (Widyawati, 2014 : 152). Berkaitan dengan kasus yang terjadi di Myanmar bahwa kejahatan tersebut sudah terjadi setelah Mahkamah Pidana Internasional resmi berlaku.

Walaupun Myanmar bukan merupakan Negara peserta yang ikut meratifikasi Mahkamah Pidana Internasional, akan tetapi bukan menjadi alasan kejahatan yang terjadi terhadap etnis rohingnya tidak dapat diadili melalui Mahkamah Pidana Internasional. Karena semua warga Negara berada dibawah yurisdiksi Mahkamah Pidana Internasional dalam kondisi seperti; Negara tempat terjadi sengketa telah meratifikasi Statuta Mahkamah Pidana Internasional. Negara tersebut telah mengakui yurisdiksi Mahkamah Pidana Internasional dalam dasar ad hoc. Dewan Keamanan PBB menyampaikan sengketa ini ke Mahkamah Pidana Internasional,

sehingga kasus ini dapat diadili menggunakan Mahkamah Pidana Internasional (Susanti, 2014 : 19).

Dari pemaparan di atas peneliti dapat menarik hasil terkait dengan upaya penyelesaian sengketa tindak kejahatan genosida ditinjau dari perspektif hukum pidana internasional. Sengketa yang terjadi di Myanmar merupakan sebuah kejahatan internasional genosida, maka upaya penyelesaiannya dapat dilakukan dengan berbagai cara selain secara hukum pidana internasional penyelesaian sengketa juga dapat dilakukan dengan cara di luar pengadilan seperti mediasi dan negoisasi. Tetapi dari cara penyelesaian sengketa secara pidana internasional, terkait dengan sengketa yang terjadi tersebut maka penyelesaiannya dapat ditangani oleh Mahkamah Pidana Internasional meskipun Myanmar bukan merupakan Negara peserta yang ikut meratifikasi Mahkamah Pidana Internasional namun semua orang berada dibawah yurisdiksi Mahkamah Pidana Internasional.

Semua warga Negara berada dibawah yurisdiksi Mahkamah Pidana Internasional karena pertama, negara tersebut ikut meratifikasi Statuta Mahkamah Pidana Internasional, kedua, negara tersebut mengakui yurisdiksi dari Mahkamah Pidana 
Internasional dalam dasar ad hoc, ketiga, Dewan Keamanan PBB menyampaikan sengketa ini ke Mahkamah Pidana Internasional, sehingga kasus ini dapat diadili menggunakan Mahkamah Pidana Internasional (Susanti, 2014 : 19).

\section{SIMPULAN DAN SARAN Simpulan}

Tindak kejahatan yang dilakukan oleh pemerintah Myanmar terhadap etnis muslim rohingnya dapat dikatakan sebagai tindak kejahatan internasional genosida, karena sudah memenuhi beberapa unsur pokok yaitu pembunuhan masal, diskriminasi terhadap agama yang minoritas, dilakukan secara sitematis, dan bertujuan untuk melenyapkan suatu etnis dan golongan tertentu, maka dari hal tersebut peneliti menganalisis bahwa kejahatan tersebut dikatagorikan sebagai kejahatan internasional genosida.

Terkait dengan penyelesaian sengketa yang terjadi tersebut maka peneliti memberikan analisis terkait dengan penyelesaian sengketa yang terjadi di Myanmar, sengketa tersebut dapat diselesaikan dengan cara di luar pengadilan dan di dalam pengadilan. Apabila di luar pengadilan penyelesaian sengketa dapat dilakukan dengan cara mediasi dan negosiasi, tetapi apabila dilakukan di dalam pengadilan yang dalam hal ini adalah berlaku pengadilan internasional maka sengketa tersebut dapat ditangani oleh Mahkamah Pidana Internasional. Karena semua warga Negara berada dibawah yurisdiksi Mahkamah Pidana Internasional.

\section{Saran}

Diharapkan dengan adanya penelitian ini dapat memberikan gambaran khususnya terhadap pemerintah Myanmar, bahwasannya tindakan yang dilakukan tersebut merupakan tindak kejahatan internasional genosida yang sudah menyebabkan penderitaan terhadap masyarakat etnis rohingnya. Diharapkan dengan adanya penelitian ini khususnya terhadap masyarakat muslim rohingnya agar selalu melakukan upaya damai agar kekerasan yang terjadi bisa segera terselesaikan. Diharapkan dengan adanya penelitian ini khususnya terhadap pembaca dapat menambah ilmu dibidang hukum khususnya yang terkait dengan kejahatan yang bersifat internasional serta peradilanperadilan yang ada di dunia.

\section{DAFTAR PUSTAKA}

Bustamam Ridwan, 2013. Jejak Komunitas Muslim di Burma (Fakta Sejarah Yang Terabaikan), Badan Litbang dan Diklat Kementrian Agama

Effendi, Tolib. 2014. Hukum Pidana Internasional. Yogyakarta : Penerbit Pustaka Yustisia

Geraldi Aldo Rico. 2013. Penyiksaan Falun Gong Oleh Pemerintah Republik Rakyat China Terkait Konvensi Anti Penyiksaan Tahun 1984. Skripsi. Jurusan IImu Hukum, Universitas Udayana.

Kurniawan Indra Yogie, Penegakan Hukum Terhadap Pelaku Pelanggaran HAM Berat Dalam Konflik Bersenjata Antara Serbia Dengan Bosnia- Herzegovina Tahun 1992-1995. Fakultas Hukum Universitas Sebelas Maret Surakarta, 2017

Kewarganegaraan: Study Kasus Etnis Rohingnya, Myanmar. 2012

Kurniawan Indra Yogie, Penegakan Hukum Terhadap Pelaku Pelanggaran HAM Berat Dalam Konflik Bersenjata Antara Serbia Dengan Bosnia- Herzegovina Tahun 1992-1995. Fakultas Hukum Universitas Sebelas Maret Surakarta, 2017.

Parthiana, Wayan. 2015. Hukum Pidana Internasional. Bandung : CV. Yrama Widya

Winarwati, Indien. 2017. Hukum Pidana Internasional. Malang : Setara Pres

Susanti Aviantina. 2014. Penyelesaian Kasus Pelanggaran HAM Berat Terhadap Etnis Rohingnya Di Myanmar Berdasarkan Hukum Internasional

Siswanto, Arie. 2015. Hukum Pidana Internasional. Yogyakarta : C.V Andi Offset

Tamia Dian Ayu Faniati, Tinjauan Hukum Internasional Terhadap Etnis Yang Tidak Memiliki

Widyawati, Anis. 2014. Hukum Pidana Internasional. Jakarta : Sinar Grafika 
e-Journal Komunitas Yustitia Universitas Pendidikan Ganesha Jurusan IImu Hukum (Volume 1 No. 1 Tahun 2018)

Soetjipto, Ani. 2015. Ham dan Politik

Internasional. Jakarta : Yayasan Pustaka Obor Indonesia 